\title{
The Global Alt-Write or why we should read reactionary (world) literature
}

\section{(World) Literature in tumultuous times: three random (but telling) scenes from our present}

Scene 1: The images that marked the 2017 Frankfurt Book Fair had nothing to do with literary prizes, memorable writers' speeches, or any other of the usual little storms in the teacup of the world's biggest marketplace and trade fair for books. On the contrary, it were not words but fists that flew at the exhibition booth of what currently has to be considered Germany's most important publisher of fiction and essays of the New Right that, as in many other countries around the world, has been gaining ground in the political and public sphere: the violent brawl between right and left-wing activists during a book presentation of Antaios was a rude interruption of the accustomed and undisturbed fluency of rights and licenses and the well-rehearsed rituals of mutual assurance of (World) Literature's importance and its progressive politico-cultural consensus.

Scene 2: Only a few months earlier, the Berlin-based bookstore Topics had to close its doors due to an incident that was not linked to direct physical violence but to the tremendous power and dynamics of internet flame wars: as a reaction to the announcing of a discussion about the work and life of the Italian fascist thinker Julius Evola a storm of protest ran over the little bookstore in Berlin's "alternative" neighborhood Neukölln. The campaign, orchestrated by several "leftist” groups, finally led into the store's economic collapse and was marked by a special kind of absurdity: both Amir Naaman and Doron Hamburger, the two Israeli owners of the bookstore, stem from families of holocaust survivors and had to face the accusation of "being Nazis" for providing a space of discussion about a controversial and reactionary author who has been gaining renewed attention in the context of the raise of the so called Alt-Right-movement in the US and beyond.

Scene 3: In January 2018 the literary world of France, used to political scandals and ideological feuds like no other, was shaken twice in a single month by revenants of its own past: First, the Haut Comité aux Commémorations nationales proposed to honor in its annual calendar the 150th birthday of Charles Maurras, best known for being one of the key figures of Action française. The decision caused 
indignation among a wide range of organizations and politicians who criticized this act of recognition of an anti-democratic and anti-Semitic author. A similar discussion arose with regard to Gallimard's plan of a re-edition of Louis-Ferdinand Céline's anti-Semitic pamphlets. The protest, in which even members of the French government were involved, led to a postponing and modification of the plan by the publisher's head Antoine Gallimard who insists, nevertheless, in realizing the publication in order to present the author of Voyage au bout de la nuit as an example of the "coexistence du génie et de l'ignoble en un seul homme".

Three things become evident by considering these random but telling scenes of current debates in the literary world: first, the often neglected fact that the universal (and particularly Western) history of ideas and literature includes a large (and often too willingly ignored) tradition and an uncomfortable cultural heritage of authors and texts that are obviously incompatible not only with the values of the democratic, "enlightened", and (mostly) cosmopolitan societies of our times, but especially with the liberal ethico-political consensus of the cultural field and the Humanities as its academic counterpart; second, the evidence that the return of a new kind of right-wing and reactionary movements all over the globe is accompanied by a more or less explicit recourse to this tradition of the history of ideas and its key-figures; and third, the insight that this kind of "reactionary" thinking and politics are not - and against the deep convictions of what we might call the "liberal center" of Western societies" ${ }^{1}$ - confined to closed national realms but act with a high degree of mobility within a network on a global scale.

With this in mind, the first lesson to learn for this liberal center would be the recognition that many of its convictions regarding determinate forms of talking, living, and even thinking, considered to be essentially liberal or "leftist", are no longer compatible with this function of a political and cultural selfassurance and identity. For instance, "mobility" as a kind of "magic word" within the global and cosmopolitan imaginaries, discourses, and practices of our time, which the idea of World Literature (and its academic adaptations) perfectly coincided with, loses its euphoric notion of an end in itself if we consider the fact that circulation does not represent an exclusive value of the liberal center but equally of the New Right and its ideas. The images of Steve Bannon

1 For a profound discussion of this "milieu” I would like to remit to Andreas Reckwitz' recent and luminous sociological study on the Society of singularities that is currently being translated into English and has to be considered one of the key-works of the discipline in the last twenty years. The study traces the multiple social, cultural, and political features of these new Western middle-classes based on a "apertistisch-differentieller Liberalismus" whose intrinsic relation to the cosmopolitan stances of the current field of World Literature studies will be addressed in the course of this article (Reckwitz 2017). 
praising transnational cooperation between the enemies of the liberal order "Reactionaries of the world, unite!" would certainly be the renovated (anti-) marxist formula for the 21st century - or the coincidence of the leaders of the Austrian Identitarian Movement, the leading thinkers of the German New Right and a figure like the masculinist and racist US-author Jack Donovan at a snowy manor in the woods of Eastern Germany may be proof enough that not everything that circulates is doing so for good. The same goes for certain formats of media performances and rhetorical strategies, originating in counter-culture and widely copied by reactionary movements ${ }^{2}$ as well as for the conviction that historically discriminated forms of (sexual) identity would necessarily go hand in hand with other elements of emancipatory politics. ${ }^{3}$ It is in view of these multiple global crises, new political and cultural ambiguities, the fundamental shift in the optimistic notion of the global (neo)liberal order (and its related dominating discourses of universality and cosmopolitanism), as well as the new rise of a Global Right with a sharp consciousness of its own history of ideas and literature, that Humanities and, particularly, the field of World Literature studies have to interrogate themselves about how to react on their part to this situation and to rethink their own theoretical and ideological premises, as well as their analytical practices.

\section{World Literature and (the limits of) cosmopolitanism}

It is not really a new insight that the rise of the academic field of World Literature in the past two decades has to not only be situated within the framework of a historical phase of intensified globalization but that it must also be considered as a field of Literary Studies that - more than any other perhaps - is based on a specific set of normative ethical assumptions regarding the (beneficent) role of literature and, particularly, World Literature. This optimism about the "democratizing strand of World Literature" (Levine/Mani 2013: 147), however, stems from a determinate idea of cosmopolitanism, which is not surprising insofar as "both world literature and cosmopolitanism are closely related

2 See, for instance, George Hawley's study (2017) on media phenomena like 4chan and others in the context of the Alt-Right-movement.

3 On this topic see the essay of the French LGBT-activist Didier Lestrade (2012) on reactionary tendencies within the gay-movement. I owe my thanks to my colleague Markus Lenz for this reference. 
concepts” (Dominguez 2012: 245). In the recent past, the connection between reading fictions, its "sympathetic effects", and cosmopolitanism was most prominently articulated by authors such as Martha Nussbaum and Kwame Anthony Appiah. For example, Nussbaum postulates in her widely-discussed book Cultivating Humanity: "[N]arrative imagination is an essential preparation for moral interaction. Habits of empathy and conjecture conduce a certain type of citizenship and a certain form of community: one that cultivates a sympathetic responsiveness to another's needs" (Nussbaum 1997: 90). According to Nussbaum's argument, the reading of fictional texts - and the study of "non-western cultures" in particular - as well as the associated capacity for putting oneself in another's position in a gesture of empathy, enables literature to fulfill an essential task in the affective education of mankind and the formation of cosmopolitan citizens of the world: "When we see in how many different ways people can organize their lives we will recognize [...] what is deep and what is shallow in our own ways, and will consider that 'the only real community is one that embraces the entire world"” (Nussbaum 1997: 158). Without neglecting the fact that the view articulated here by Nussbaum has given rise to manifold discussions, her position can hold to be representative for a dominant affirmative propagation of the cosmopolitan potential of (world) literature in current debates positing that "access to world literature might be a way out of what Susan Sontag calls 'compulsory provincialism"” (Levine/ Mani 2013: 246).

However, the notion of "diversity", as conceived of by these concepts of cosmopolitanism and World Literature, is limited and normative in the sense that the very idea of World Literature as "windows on different parts of the world" (Damrosch 2003: 24) as a rule does not simply comprise texts from (theoretically) all parts of the globe or all "topics" but does so from a determinate perspective: "diversity" and "world" mean, from the vantage point of the cosmopolitan pedagogical agenda, ${ }^{4}$ basically the reading of "foreign" texts being suitable for reading experiences of those "different ways people can organize their lives" that actually meet emancipatory expectations, that is, to access in their majority historically disregarded and/or discriminated cultural, geographical, linguistic or identity-related representations in literary texts. We may consider, on the one hand and from an ethical point of view, this reading politics as a useful and justified means of breaking with established historical imbalances in terms, for instance, of a literary canon dominated by white, Western, and male authors in favor of a much more diverse range of texts, languages, and subjectivities; on the

4 See for example the contributions in Damrosch (2012). 
other hand, we cannot deny that these (again: from an ethical and historical perspective fully justified and desirable) reading programs run the risk of transforming World Literature studies into a politically biased discipline unable to properly meet their own mission of giving important insights into the complexity of the (whole) world.

I am well aware of the fact that many scholars in the field may read my objection as conservative and inappropriate considering that every (re)formation of the literary canon implies unavoidably new (and even very reasonable) imbalances and that the critical potential of Humanities cannot be separated from certain ethical and normative stances. However, it suffices to examine some of the most prominent World Literature anthologies, collected volumes, or conference programs to make sure that the effective canon of World Literature studies does by no means comprise potentially "all literary works that circulate beyond their culture of origin, either in translation or in the original language" (Damrosch 2003: 4) but possesses an intrinsic proximity to a rather narrow range of authors, texts, and topics strengthening the impression of redundancy and solipsism in parts of the field's scholarship - a problem that arises, in my opinion, to a great extent from the specific cosmopolitan basis of World Literature studies. This relationship has caused a whole series of problems of "translation", as César Domínguez has argued lucidly by asking: "How to translate, for example, cosmopolitanism as a project linked to 'human rights' and, indirectly, to 'democracy' [. . . ] into world literature? As a globalized version of littérature engagée?” (Domínguez 2012: 248). Similarly, Emily Apter has criticized World Literature as "an encapsulating model of literary comparatism that, in promoting an ethic of liberal inclusiveness or the formal structures of cultural similitude, often has the collateral effect of blunting political critique” (Apter 2013: 41). The crucial point here, however, is not to dismiss completely the ethical substance of World Literature informed by this kind of cosmopolitanism (or of the Humanities as a whole) but to stress "the need for a more critical stance towards cosmopolitanism” (Domínguez 2012: 246) in the sense Peter Hitchcock does when he posits "an indifferent methodology, one that does not presume that a celebration of difference in world literature [. . . exhausts the ethical responsibility which the crisis in 'world' involves today" (Hitchcock 2012: 367).

In view of the fact that "the concept of 'world' does not allow us to posit it as an ethical resource" any more, ${ }^{5}$ Hitchcock argues that "attending to the process of contravention itself is more important than producing a moral guide premised

5 On the problematization of the concept of world understood as a horizon of expectations and emancipation see also Mariano Siskind's article in this volume. 
on the otherwise implicit gesture of worldly accumulation (gathering the world, as it were, through literature)" (Hitchcock 2012: 372). This perspective on the concept seems closely related to what Gerald Delanty has coined "critical cosmopolitanism":

Cosmopolitanism can be held to be a critical attitude [...], an analysis that is essentially critical in that it is an approach to social reality that views social reality not only as an empirical phenomenon, but also as a given form by counter-factuals. [...] The cosmopolitan condition emerges out of the logic of the encounter, exchange and dialogue and the emergence of universalistic rules rather than by the assertion of a higher order of truths. (Delanty 2012: 42)

Consequently, such a definition of cosmopolitanism does not aim to foreground a certain set of values which, applied to World Literature studies, should be "contained" in texts suitable for the pedagogic purposes of "sympathetic" readings; rather, it focuses on a radical openness, understanding the idea of "world" primarily as an assemblage of highly contingent views of the world that hardly can be subsumed under normative ethical concepts the way "traditional" cosmopolitanism does. Critical cosmopolitanism implies, as Dalenty argues further, a concept of "post-universalistic truth", which means that "statements of truth and justice, etc., are not absolute, immutable or derivable from an objective order of universal values, but nonetheless it is still possible to make judgments and evaluations" (Delanty 2012: 42). Hitherto this kind of critical cosmopolitanism has been applied in World Literature studies particularly to non-Western or marginalized spaces and phenomena undermining the dominant materialist, formal or epistemological categories of the concept. ${ }^{6}$ However, I would like to give it a different turn by focusing not on the obvious possibilities of this radical openness in the form of "dissident" subjectivities, materialities or epistemologies but rather on "world views" situated beyond and against the very idea of cosmopolitanism (and its related optimistic assumptions on the world and human beings). The complex embodying this set of ideas is what can be addressed by the term "reaction" - a controversial concept, which does not seem to have much in common with World Literature at first sight but whose global dimensions and importance for current scholarship (not only) in this field I will try to explore in what follows.

6 See for example the study on alternative forms of circulation of World Literature in Colombia by Domínguez (2018) operating deliberately with Delanty's concept of critical cosmopolitanism. 


\title{
"And yet it moves" - "reaction" as "travelling concept" and dimensions of "reactionary world literature"
}

\begin{abstract}
What is reaction? Consult any decent university library and you will find hundreds of books in all the world's major languages on the idea of revolution. On the idea of reaction you will be hard put to find a dozen. We have theories about why revolution happens, what makes it succeed, and why, eventually, it consumes its young. We have no such theories about reaction, just the self-satisfied conviction that it is rooted in ignorance and intransigence, if not darker motives. (Lilla 2016: ix)
\end{abstract}

The observation formulated by Mark Lilla in his recent study on reactionary elements in the history of ideas can be perfectly applied to Literary Studies as well, where conservative and reactionary authors and topics hardly find their way into contemporary syllabi, canons, and scholarship. Actually, the study of conservative or reactionary literature seems to be a sort of "parallel world" as its authors and ideas are investigated mainly by scholars or philosophers exposing their own conservative political positions, and as the majority of these authors (and the corresponding scholarship) are published by specific publishing houses or journals. While there exists a strong and established tradition of literary studies on socialist, proletarian, or "leftist" literature, you will be hard put to find similar tendencies for "right" or "reactionary" literature - a fact deeply rooted in the history of the Humanities' political orientations since the second half of the 20th century, or as Kate Macdonald argues in her study on conservative popular fiction in Britain:

Modern literary criticism has been interested in writing that focuses on political manifestations such as feminism, Marxism and its variations, and postcolonialism. It is predicated on writers of the Left as the norm, the model for literary activity, those who were deeply concerned with politics. Consequently those writers who were not solely political, and popular writers of the Right who focused most obviously on social rather than political disapproval, were not permitted the critical status that could have allowed them to function as counterbalancing voices. (Macdonald 2015: 14) ${ }^{7}$

7 A similar observation has been made by Ian Hall regarding the leading perspectives and theories in Political Science and International Studies that while being "dominated by realists and internationalists, it is also true that many others have made significant contributions from the fringe - whether radical or reactionary - and that those contributions have stimulated realist and internationalist thought” (Hall 2015: 2). 
Reactionary literature seems to be suspect to the "enlightened" mainstream of Humanities and particularly to World Literature studies: while historians of ideas, for instance, have recently (re)turned to the global dimensions and forms of circulation of reactionary thinking and counter-enlightenment (continuing a tradition set up by thinkers like Isaiah Berlin), ${ }^{8}$ there does not exist anything comparable in World Literature studies. ${ }^{9}$ This is all the more astonishing in view of the historical proximity of enlightenment-cosmopolitanism (as the underlying idea of World Literature) and counter-enlightenment or reactionary discourses stressing the importance of the nation and national literatures. Maybe it was Goethe's fault when he declared that "National literature does not mean much these days" that World Literature studies do not seem to have been interested at all in what has to be considered the ontological antipode of their global dreams. Be it as it may, this lack promotes the need to take into consideration "the twofold historical function of discourses of cosmopolitanism", as Galin Tihanov argues, that is,

to trace and reflect upon the processes of expansion of the polis, and of the fields available to it for its cultural self-identification, but also to chart and register the reverse process [...] - that of erecting firmer barriers and directing the purposeful contraction, narrowing down, and self-isolation of the polis. (Tihanov 2011: 144)

If cosmopolitanism and World Literature are bound to specific historical fluctuations, ${ }^{10}$ so are their critical counterparts of reaction, from where arises the necessity to shift our attention to this "dark side of the globe" accompanying "progressive" discourses (cosmopolitanism forms part of) like a shadow. This kind of historical dialectics has been commented likewise by thinkers like Karl Mannheim in his seminal study on conservatism as a "historically embedded, dynamically changing structural complex" (Mannheim 1999: 75) or Albert O. Hirschman in his observation of different "reactionary waves" in the history of ideas in the face of determinate progressive demands like natural rights and universal suffrage in the 19th or politics of social welfare in the 20th century

8 See for example the globally-oriented works of Mark Sedwick and Nicholas Goodrick-Clarke on anti-modernity and Nazism or Graeme Garrard's book on counter-enlightenment.

9 This does not mean that there would not exist any important works on national literary traditions of reaction (see, for instance, the excellent and fundamental two-volume study by Julio Rodríguez Puértolas on fascist Spanish literature or Antoine Compagnon's seminal work on anti-modern authors in France).

10 See for example the comments by Tihanov about post-World War II Soviet Union where according to shifts in cultural and foreign politics at the end of the 1940s - "comparative literature became quite literally a dangerous profession” (Tihanov 2001: 145). 
(Hirschman 1991: 11-42). The dominance of cosmopolitan discourses (and World Literature as its literary counterpart) in the context of the recent phase of globalization, I would argue, can be read in line with these dialectics and taken as one among different reasons for the contemporary and massive return of "reaction" as a formation of ideas and characterized, as Hirschman analyzed lucidly, by a specific "rhetoric". Hence, both "Cosmopolitanism" and "Reaction" should be considered as mutually entangled, essentially dynamic and changing concepts within specific historic constellations. Consequently, they depend on a wide range of rhetorical and performative strategies (and should not be considered as a supposedly static set of determinate values). The terminological blurring of "reaction" likewise has to do with this sort of mutability, as Hall argues:

By its very nature, because it is reactive, responding to the theories and practices of others, reactionary thinking is arguably even harder to define than radical thought. It can look backward to an idealized past or forward to an idealized future. It can be near-anarchist and strongly statist, but it generally shares some core features with realist thinking - especially in its emphasis on the centrality of power and violence in politics. (Hall 2015: 8)

Against this background, the degree of "reaction" inherent to a literary text should be defined likewise, as Claus-Michael Ort proposes, in relation to its "connection to 'conservative' discourse [...] [and] situated on a scale of different degrees of manifestation and implications of 'conservative' figures of thought and semantics" (Ort 2013: 35-36).

The crucial point for World Literature studies, which makes "reactionary literature" a genuine object of interest for the field, is the fact mentioned above that "reaction" itself is not only a historically mutable phenomenon but also (to use an expression coined by Mieke Bal) a sort of "travelling concept". At first glance, this idea may seem a little odd, given the essentialist and rather "antiexpansive" orientation generally ascribed to reactionary thinking. However, a closer look at different phenomena of cultural and literary reaction in the context of modernity reveals the essentially mobile and transnational character of this ideological complex and its institutions. In this context, fascism would probably be the most illustrating example (despite the fact that there could be more than one reason for considering the impetus of this ideological current more revolutionary than reactionary). It was in this spirit, for instance, that Hannah Arendt talked about a "Fascist International" arguing that "modern antiSemitism was never a mere matter of extremist nationalism: from the very beginning it functioned as an International" (Arendt 1945: 141). On an institutional level, the recent and outstanding book by Benjamin Martin has pointed out the fundamentally transnational character of fascist cultural politics: 
Founding multilateral institutions with regular conferences, subcommittees, and multilanguage journals, Nazis and fascists deftly deployed what have been called "the mechanics of internationalism" for political ends antithetical to the internationalist spirit. [...] [T]he totalitarian internationalism of the Nazi-fascist Axis offered the specter of something else: a model of transnational cooperation based on the values of the most intense, aggressive, and racist national spirit. ${ }^{11}$ (Martin 2016: 6-7)

In a similar way, other and more recent reactionary movements like the Nouvelle Droite in France, founded and shaped by a circle of intellectuals around Alain de Benoist, not only departed from a "'Gramscism of the Right' by which the intellectual extreme right could counter the metapolitical hegemony of the intellectual left" (Shurts 2017: 281) but were essentially conceived as a transnational projects with a specific vision of the world (and its cultural divisions) in the sense of what the actual New Right across the globe continues to call "ethnopluralism", i.e. an idea of "diversity" absolutely contrarian to the cosmopolitan one but with precise internationalist implications, or as de Benoist has argued: "I define the Right as that attitude which wants to take into consideration the diversity of the world. Consequently the relative inequalities which necessarily follow from this diversity are good. The homogenization extolled in the discourse of egalitarian ideology is evil" (cited in Shurts 2017: 292). This notion of "diversity", whose origins can easily be traced back to reactionary thinkers of the 19th century such as Joseph de Maistre, keeps operating in the political and cultural imaginary of the Global New Reaction from Bannon's Alt-Right to the Polish PiSparty, from Le Pen's Front (now: Rassemblement) National to the German Alternative für Deutschland and Putin's, Erdogan's or Modi's nationalist programs that consider - exactly like Alain de Benoist - "Culture" as one of their primary battlefields. Even if this sort of "reactionary internationalism" is still in its beginnings there is no reason to suppose that the whole fuss would soon go up in smoke. ${ }^{12}$ Considering these different movements as a whole, they represent what

11 Federico Finchelstein defines fascism in a similar way as "a global ideology undergoing constant transformation. Beyond national contexts and restricted theories, fascism then becomes a traveling political universe, a radical nationalism affected and, to some extent, constituted by transnational patterns" (Finchelstein 2010: 6).

12 To give just one example from the German context: as any other political party represented in the national parliament, the Alternative für Deutschland has the right to obtain substantial funds of millions of euros for its own political foundation. This kind of institutions traditionally function as think-tanks, cultural players, and (with their university awards system) as powerful ideological training grounds for the different political camps, which is why the presence and influence of reactionary positions particularly in the cultural sector will grow in the near future. Likewise, it can be expected that the degree of internationalization will augment as well, materializing itself in a similar way to fascist internationalism seventy years ago with 
Kwame Anthony Appiah has called "counter-cosmopolitanism" in the sense "that they exemplify the possibility of a kind of universal ethics that inverts the picture of cosmopolitanism" (Appiah 2007: 140). With this in mind, the remaining question (of this topic's very short outline) would be how World Literature studies might approach "Reactionary World Literature" in the context of the current political landscape and some of the sketched impasses of their traditional cosmopolitan orientations.

\section{Reading the Global Alt-Write: perspectives for world(ly) literary studies}

It is in the spirit of the outlined situation that World Literature studies should consider "reactionaries" or "counter-cosmopolitans" as a genuine object of study for the field (and far beyond the scarce existing examples in this context related basically to aspects of translation ${ }^{13}$ ). Certainly, this would mean dismissing some of traditional cosmopolitanism's convictions with regard to literature, namely the cited idea of its "sympathetic" effects - a notion that has come under increasing pressure in contemporary research whenever authors, as Suzanne Keen does in her study Empathy and the Novel, have asserted that

[N]o evidence emerges [. . . ] that would support a judgment about the importance or insignificance of novel reading in cultivating the sympathetic imaginations. [...] [T]his lack of information does not preclude influence through fiction reading, to be sure, but it does warrant caution when making claims about the formation of these particular good world citizens. (Keen 2007: 23) $)^{14}$

This consciousness of the fundamental ambivalence of narratives, as stated by Keen, would be a first step in this direction to break up the over-optimistic discourses dominating particularly in World Literature studies with regard to their

its "sustained effort to remake the international structures of European cultural life, creating a rival network of institutions and individuals from across Europe in a radical right-wing form of international cultural cooperation" (Martin 2016: 4).

13 As Gisèle Sapiro pointed out, "[p]olitical and broader ideological factors may trigger or hinder the circulation of literary texts. Translation may serve political or ideological objectives; it can be a means to disseminate a doctrine or a vision of the world" (Sapiro 2016: 83). A good example regarding the translation politics in fascist Italy provides the study by Giorgio Fabre (2007).

14 For an exemplary reading of this aspect see my comparative study on J.M. Coetzee and Roberto Bolaño (Loy 2018b). 
object of study. When literary texts, as Pheng Cheah argues, possess a genuine quality of "worlding" - why should this fact only be applicable to "progressive" or cosmopolitan imaginaries and ideas? Or citing another point from Keen's reflections in reference to the example of the Holocaust and the question to what extent the narrative of the inhumane, situated for example in language about the racial superiority of Aryans in Nazi ideology, must be discussed in connection with the power of fictions: "The content of stories is not a neutral matter. If narrative fiction has the capacity to alter readers' characters for the good, it may also possess darker powers" (Keen 2007: 25). In a similar way and in line with the sketched global dimensions of reaction, World Literature studies would have to say farewell to the idea that their privileged categories of analysis like circulation, translation, or intellectual exchange remain limited to phenomena of progressive cosmopolitanism. This becomes apparent by considering the fact that their opponents have successfully developed their very own versions of World Literature as Mani has pointed out in his study of the literary politics in the Third Reich:

The irony with the Nazis - who denounced literature written by Weltbürger with a Weltanschauung - is that instead of completely denouncing world literature, they redefined, redesigned, and reinvented it to fit their ideological program. Much as they appropriated books and libraries as 'weapons' in the service of state ideology, so did they deploy world literature in the creation of a very specific political world for the German reader. (Mani 2017: 155)

Those who prefer to consider this sort of politics as a matter of the past should not ignore the fact that there already exist new attempts from within Literary Studies to revert established canons and readings of World Literature in order to adjust them to a reactionary world view. A fine example of this has been recently provided by the overtly reactionary German philologist and publicist Günter Scholdt reading a total of thirty classics, ranging from Aesop to García Márquez, and (re)politicizing them according to current topics of the New Right. ${ }^{15}$ Even if his readings do not lack a whole series of absurdities erecting, for instance, figures like Don Quijote or García Márquez's Coronel Buendia as conservative mavericks and examples to follow against an supposedly oppressive reality or a corrupt state - they give a good idea of what a reactionary literary criticism of the (very near) future might look like. Likewise, there has been hardly dedicated any attention by World Literature

15 See also my review of the book for the German newspaper Die Zeit (Loy 2018a). 
studies to these otherwise so central "Institutions of World Literature" 16 when it comes to reactionary texts. The translation politics of publishers like the already mentioned Antaios in Germany, for instance, publishing a wide range of historical and contemporary French reactionaries, and many others that contribute to the worldwide circulation of texts and ideas would certainly offer enough material for an analysis of this Global Alt-Write and its promoters.

While the latter would rather meet a certain type of materialist criticism prominent in World Literature, the question to what extent reactionary authors should be part of teaching and syllabi of World Literature concerns not only comparative approaches but traditional and nationally oriented philology as well. In times of growing "safe spaces" and "trigger warnings", this step certainly represents the most radical counterproposal possible. However, I would argue that in view of the return of the Global Alt-Write the need for a deeper knowledge about the origins and trajectories of a reactionary history of ideas and literatures should be quite evident. As Umberto Eco stated in an essay on 14 general features of fascism, ${ }^{17}$ reactionary imaginaries are - like all imaginaries, I would risk adding - essentially syncretic working with different fragments of the history of ideas that - and this would be the critical pedagogical mission of teaching "Reactionary World Literature" - must be properly identified as such by contemporary readers. However, this kind of knowledge presupposes "uncomfortable readings" situated far beyond any kind of "safe space" a fact that Martin Puchner highlighted as a general necessity for teaching, as he calls it, not World but Worldly Literature that is "literature in the thrall of empires, victim and facilitator of conquests. Worldly literature is not discrete, delicate, and benign, but embraced by the world, is made for the world, and put in the service of worldly purposes" (Puchner 2012: 258).

This kind of cultural knowledge about reaction as the "faithful shadow" of enlightenment, progress, and cosmopolitanism would also mean a significant contribution to a more balanced and informed behavior in face of deviant political opinions: instead of denouncing in an inflationary way every conservative position as either "reactionary" or "fascist" (as it is currently happening in numerous cases in public debates and over-politicized sections of the academia) the consciousness of determined traditions of terms like "conservatism", "reaction", and "fascism" doubtlessly would be a mean to regain a more civilized

16 See the outstanding volume by Stefan Helgesson and Pieter Vermeulen (2016).

17 I owe my thanks for this reference to my colleague Markus Messling whose brilliant work on racism and philology in the 19th century gives another form of insight into the large and problematic history of our discipline and is of vital importance in the context of the entanglements between the Humanities and Reaction (see Messling 2016). 
form of public discourse.$^{18}$ However, the ability to recognize this kind of reactionary semantics and traditions would certainly require another form of reading as well, one that would not, as many recent currents in World Literature do, "require us to abandon close reading, with its stress on the subtlest linguistic nuances, in favor of world-systems theory and patterns of global circulation" (Levine/ Mani 2013: 142). I certainly do not aim to argue here for a naïve return to an auratic concept of reading. Nevertheless, I cannot help feeling a growing unease with some tendencies of World Literature studies that consider with a sort of disdain or compassion every approach that does not perceive of literature merely as a commodity whose problematic conditions of production have to be denounced but as that what in first place contributes to the existence of something as World Literature, i.e. its capacity to affect readers as specific form of language. The search for such a form of reading of and in World Literature would lead backward (or forward?) to a stronger philological and historical approach whose idea of the world is, as Werner Hamacher has argued, certainly very different from the increasingly dominant forms of "reading" in World Literature with their economistic-material orientations: "The fact that philology applies itself to detail, to the nuances of a detail, to the intermundia between these nuances, slows its movement in language and in the world" (Hamacher 2009: 35). If this (re)turn to philology doubtlessly possesses a conservative thread itself it is because it points to an idea as formulated in contemporary debates on the future of the Humanities by Simon During: arguing that the radically progressive orientation of the Humanities "is for the most part recent, being largely confined to the period of emancipation struggles in the 1960s" (2012: 54), During explores the question of how a reformed notion of conservatism might enable a new critical discourse in the Humanities in view of the fact that

the various post-1960s political programs that the academic humanities directed toward the larger world - the demand for justice, for recognition of oppressed identities, hopes for unimaginable revolutions to come, the description of ongoing social destitution, the demand for better and more democracy, and so on - in the end have just solidified the market-state's instrumentalization of the education sector [...] leaving the humanities in a condition of recalcitrant obedience, a straitjacketed enmity toward the state-market combination and its academic-bureaucratic machinery, an enmity neither quite neutral nor engaged and in part protected by sheer organizational inertia, but which for all that does turn us, in our search for succor and a basis for (or replacement of) critique, toward lineages of conservative refusal of the postrevolutionary order. (During 2012: 57)

18 For a discussion of this kind of difference between a conservative and a reactionary (and racist) author see my study on contemporary French authors Philippe Muray and Richard Millet (Loy 2019). 
It does not seem extremely polemic to consider the field of World Literature and particularly its materialist approaches - that even where they are able to achieve a critical potential, they fit perfectly well the academic funding systems' logics of "useful" (as in "measurable") research - as an essential part of this type of Humanities in absolute conformity with the neoliberal rules of what During calls "democratic state capitalism". Consequently, if "leftist progressivism" has become, "willy-nilly, an arm of social democratic capitalism", as During argues, "substantive negation of the system is, it would seem, being transferred to conservatism" (2012: 42). However, conservatism in During's sense should not be understood as some kind of reactionary return to a lost past but as a critical idea "that the academic humanities, insofar as they too conserve experiences of the world that oppose and stand outside technologico-Benthamitism, as F.R. Leavis famously called it, can themselves be regarded as conservative storehouses for resistances to come" (During 2012: 49). In view of the vehemence of reaction's return to the political world stage it is by no means impossible that the moment of an attack on the Humanities (and World Literature studies in particular) will occur sooner than later. Between the reactionary temptations of this (still dystopic) future, that probably will not fail to appear, and a problematic notion on World Literature studies in terms of a naïve cosmopolitanism or a sales-numbers counting economistic variant, a critical-conservative (reading) position beyond these two poles may not be the worst.

\section{Works cited}

Appiah, Kwame Anthony (2007): Cosmopolitanism. Ethics in a World of Strangers. London: Penguin.

Appiah, Kwame Anthony (2001): “Cosmopolitan Reading”. In: Dharwadker, Vinay (ed.): Cosmopolitan Geographies: New Locations in Literature and Culture. London: Routledge, pp. 199-225.

Apter, Emily (2013): Against World Literature: On the Politics of Untranslatability. New York: Verso.

Arendt, Hannah (1945): “The Seeds of a Fascist International”. In: Jewish Frontier, (June 1945), pp. 140-50.

Cheah, Pheng (2016): What Is a World?: On Postcolonial Literature As World Literature. Durham: Duke University Press.

Compagnon, Antoine (2005): Les antimodernes: De Joseph de Maistre à Roland Barthes. Paris: Gallimard.

Damrosch, David (ed.) (2012): Teaching World Literature. New York: Modern Language Association of America.

Damrosch, David (2003): What Is World Literature? Princeton: Princeton University Press. 
Delanty, Gerard (2012): “The Idea of Critical Cosmopolitanism”. In: Delanty, Gerard (ed.): Routledge Handbook of Cosmopolitan Studies. London: Routledge, pp. 38-46.

Domínguez, César (2018): "Literatura mundial en biblioburro. Un caso procomún de circulación literaria”. In: Müller, Gesine/Locane, Jorge/Loy, Benjamin (eds.): Re-mapping World Literature. Writing, Book Markets, and Epistemologies between Latin America and the Global South. Berlin: De Gruyter, pp. 119-130.

Domínguez, César (2012): “World Literature and Cosmopolitanism”. In: D’haen, Theo/Damrosch, David/Kadir, Djelal (eds.): The Routledge Companion to World Literature. London: Routledge, pp. 242-252.

During, Simon (2012): Against Democracy. Literary Experience in the Era of Emancipations. New York: Fordham University Press.

Eco, Umberto (1995): “Ur-Fascism”. In: The New York Review of Books (June 22, 1995), <https://www.nybooks.com/articles/1995/06/22/ur-fascism> (last visit: 20/08/2018).

Fabre, Giorgio (2007): “Fascism, Censorship and Translation.” In: Billiani, Francesca (ed.): Modes of Censorship and Translation. National Contexts and Diverse Media. London: St. Jerome Publishing, pp. 27-60.

Finchelstein, Federico (2010): Transatlantic Fascism. Ideology, Violence, and the Sacred in Argentina and Italy, 1919-1945. Durham: Duke University Press.

Garrard, Graeme (2006): Counter-enlightenments: From the eighteenth century to the present. London: Routledge.

Goodrick-Clarke, Nicholas (2002): Black sun: Aryan cults, esoteric Nazism and the politics of identity. New York: New York University Press.

Hall, Ian (2015): “Introduction: Radicals and Reactionnaries in Twentieth-Century International Thought". In: Hall, Ian (ed.): Radicals and Reactionnaries in Twentieth-Century International Thought. London: Palgrave Macmillan, pp. 1-15.

Hamacher, Werner (2009): “95 Theses on Philology". In: diacritics, 39, 1, pp. 25-44.

Hawley, George (2017): Making Sense of the Alt-Right. New York: Columbia University Press.

Helgesson, Stefan/Vermeulen, Pieter (2016): Institutions of World Literature: Writing, Translation, Markets. London: Routledge.

Hirschman, Albert (1991): The Rhetoric of Reaction: Perversity, Futility, Jeopardy. Cambridge: Harvard University Press.

Hitchcock, Peter (2012): “The Ethics of World Literature”. In: D’haen, Theo/Damrosch, David/ Kadir, Djelal (eds.): The Routledge Companion to World Literature. London: Routledge, pp. 365-372.

Keen, Suzanne (2007): Empathy and the Novel. Oxford: Oxford University Press.

Lestrade, Didier (2012): Pourquoi les gays se sont passés à droite. Paris: Seuil.

Levine, Caroline/Mani, B. Venkat (2013): "What Counts as World Literature? (Introduction)”. In: Modern Language Quarterly: A Journal of Literary History, 74, 2, pp. 141-150.

Lilla, Mark (2016): The Shipwrecked Mind: On Political Reaction. New York: New York Book Review.

Loy, Benjamin (2018a): “Bücher für Wutbürger. Günter Scholdts neurechte Deutung des Kanons der Weltliteratur". In: DIE ZEIT, 14, p. 48.

Loy, Benjamin (2018b): "The Precarious State of the Art: Writing the Global South and Critical Cosmopolitanism in the Works of J.M. Coetzee and Roberto Bolaño". In: Müller, Gesine/Locane, Jorge/Loy, Benjamin (eds.): Re-mapping World Literature. Writing, Book Markets, and Epistemologies between Latin America and the Global South. Berlin: De Gruyter, pp. 91-116. 
Loy, Benjamin (2019): “Ordnungsrufe - Formen und Funktionen 'reaktionären Denkens' im französischen Essay der Gegenwart”. In: Biersack, Martin/Hiergeist, Teresa/Loy, Benjamin (eds.): Parallelgesellschaften: Instrumentalisierungen und Inszenierungen in Politik, Kultur und Literatur. Munich: Akademische Verlagsgemeinschaft München, pp. 177-193.

Mannheim, Karl (1999): Conservatism: A contribution to the sociology of knowledge. Collected Works Volume Eleven. Eds. David Kettler, Volker Meja, Nico Stehr. Trans. David Kettler, Volker Meja. London: Routledge.

Mani, B. Venkat (2017): Recording World Literature. Libraries, Print Culture, and Germany's Pact with Books. New York: Fordham University Press.

Martin, Benjamin (2016): The Nazi-fascist new order for European culture. Cambridge: Harvard University Press.

Messling, Markus (2016): Gebeugter Geist. Rassismus und Erkenntnis in der modernen europäischen Philologie. Göttingen: Wallstein.

Macdonald, Kate (2015): Novelists Against Social Change. Conservative Popular Fiction, 1920-1960. London: Palgrave Macmillan.

Nussbaum, Martha (1997): Cultivating Humanity. A Classical Defense of Reform in Liberal Education. Cambridge: Harvard University Press.

Ort, Claus-Michael (2013): “Literarischer “Konservatismus’: Denkstil - Habitus - Diskurs?”. In: Schmidt, Maike (ed.): Gegenwart des Konservatismus in Literatur, Literaturwissenschaft und Literaturkritik. Kiel: Verlag Ludwig, pp. 19-42.

Puchner, Martin (2012): “Teaching Worldly Literature”. In: D’haen, Theo/Damrosch, David/Kadir, Djelal (eds.): The Routledge Companion to World Literature. London: Routledge, pp. 255-263.

Reckwitz, Andreas (2017): Die Gesellschaft der Singularitäten: Zum Strukturwandel der Moderne. Berlin: Suhrkamp.

Rodríguez Puértolas, Julio (2008): Historia de la literatura fascista española. Madrid: Akal.

Sapiro, Gisèle (2016): “How Do Literary Works Cross Borders (or Not)? A Sociological Approach to World Literature". In: Journal of World Literature, 1, pp. 81-96.

Scholdt, Günter (2017): Literarische Musterung: Warum wir Kohlhaas, Don Quijote und andere Klassiker neu lesen müssen. Schnellroda: Antaios.

Sedgwick, Mark (2004): Against the modern world: Traditionalism and the secret intellectual history of the twentieth century. Oxford: Oxford University Press.

Shurts, Sarah (2017): Resentment and the Right: French Intellectual Identity Reimagined, 1898-2000. Newark: University of Delaware Press.

Tihanov, Galin (2011): “Cosmopolitanism in the Discursive Landscape of Modernity: Two Enlightenment Articulations”. In: Adams, David/Tihanov, Galin (eds.): Enlightenment Cosmopolitanism. London: Legenda, pp. 133-152. 